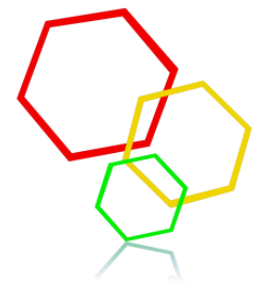

Вісник Дніпропетровського університету. Серія Хімія Bulletin of Dnipropetrovsk University. Series Chemistry

p-ISSN 2306-871X, e-ISSN 2313-4984

journal homepage: http://chemistry.dnu.dp.ua

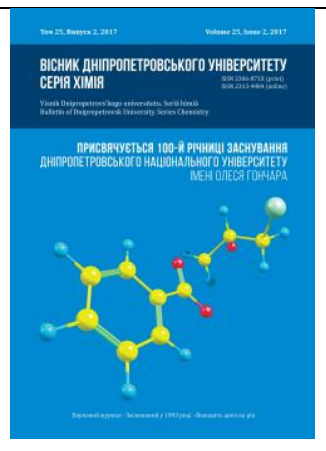

UDC 544. 6.018.462.42

\title{
POLYMER-ELECTROLYTE MEMBRANE FOR FUEL CELLS BASED ON CROSS-LINKED POLYIMIDE AND PROTIC IONIC LIQUID
}

\author{
Stanislav M. Makhno, ${ }^{1}$ Oksana P. Tarasyuk, ${ }^{2}$ Tetiana V. Cherniavska, ${ }^{1}$ \\ Oleg V. Dzhuzha, ${ }^{2}$ Valeriy I. Parkhomenko, ${ }^{2}$ Sergiy P. Rogalsky ${ }^{2 *}$ \\ ${ }^{1}$ Chuiko Institute of Surface Chemistry of NASU, General Naumov str., 17, Kyiv 03164, Ukraine \\ 2Institute of Bioorganic Chemistry and Petrochemistry of NASU, Kharkivske schose, 50, Kyiv 02160, Ukraine \\ Received 28 April 2017; revised 26 august 2017; accepted 04 December 2017
}

\begin{abstract}
The aim of this research was to develop polymer-electrolyte membrane on the base of commercial polyimide Matrimid which has high proton conductivity at elevated temperatures above $100{ }^{\circ} \mathrm{C}$. Hydrophobic ionic liquid 1butylimidazolium bis(trifluoromethylsulfonyl)imide (BIM-TFSI) has been synthesized and used as proton conducting electrolyte. The electrical conductivity of the ionic liquid determined by electrochemical impedance method was found to have a value of $10^{-3} \mathrm{~S} / \mathrm{cm}$ in the temperature range from 100 to $180{ }^{\circ} \mathrm{C}$. The composite film based on Matrimid polyimide containing $70 \mathrm{wt} \%$ of protic ionic liquid has been prepared by casting from methylene chloride solution. Polyetheramine Jeffamine ${ }^{\circledR}$ D-2000 was used as a cross-linking agent for polyimide. According to mechanical and thermal analysis data, Matrimid/BIM-TFSI composite has tensile strength of $18 \mathrm{MPa}$ and thermal degradation point of $306^{\circ} \mathrm{C}$. Electrophysical properties of polyimide film impregnated with ionic liquid was studied by two-probe technique at the frequencies of $0.1,1.0$ and $10 \mathrm{kHz}$ by using immitance meter in the temperature range from 25 to $180{ }^{\circ} \mathrm{C}$. The electrical conductivity was found to be $2.7 \cdot 10^{-4} \mathrm{~S} / \mathrm{cm}$ at room temperature and reached the value of $1.5 \cdot 10^{-3} \mathrm{~S} / \mathrm{cm}$ at $180^{\circ} \mathrm{C}$. Thus, in this work proton conducting membrane based on commercial polyimide has been obtained for the first time by simple method without additional sulfonation stage. Matrimid/BIM-TFSI composite membrane is promising for applications in fuel cells operating at elevated temperature without external humidification.
\end{abstract}

Keywords: polymer-electrolyte membrane; polyimide; ionic liquid; fuel cells; proton conductivity

\section{ПОЛІМЕР-ЕЛЕКТРОЛІТНА МЕМБРАНА ДЛЯ ПАЛИВНИХ ЕЛЕМЕНТІВ НА ОСНОВІ ЗШИТОГО ПОЛІМІДУ І ПРОТОННОЇ ІОННОЇ РІДИНИ}

Станіслав М. Махно, ${ }^{1}$ Оксана П. Тарасюк, ${ }^{2}$ Тетяна В. Чернявська, ${ }^{1}$

Олег В. Джужа, ${ }^{2}$ Валерій І. Пархоменко, ${ }^{2}$ Сергій П. Рогальський ${ }^{2}$

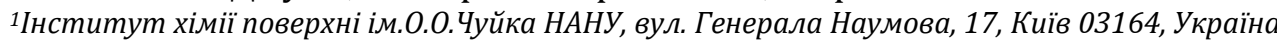

2Інститут біоорганічної хімії та нафтохімії НАНУ, Харківське шосе, 50, Київ 02160, Україна

\section{Анотація}

Метою роботи було отримання полімер-електролітної мембрани на основі промислового полііміду Маtrimid з високим рівнем протонної провідності при температурі вище $100{ }^{\circ}$ С. Синтезовано гідрофобну іонну рідину біс(трифторметилсульфоніл)імід 1-бутилімідазолію (БІМ-ТФСІ), яку використано в якості протонпровідного електроліту. Питома електропровідність іонної рідини, визначена методом електрохімічного імпедансу, має значення порядку $10^{-3} \mathrm{Cm} / \mathrm{cm}$ в інтервалі температур 100-180 ${ }^{\circ} \mathrm{C}$. Отримано композитну плівку на основі полііміду Matrimid із вмістом протонної іонної рідини $70 \%$ поливом з розчину в метиленхлориді. Поліетерамін Jeffamine ${ }^{\circledR}$ D-2000 використано в якості зшиваючого агенту для полііміду. Згідно 3 результатами механічних і термічних досліджень, міцність на розрив композиту Matrimid/БIM-EФCI становить 18 мПа, а температура початку деструкції - $306^{\circ} \mathrm{C}$. Електрофізичні властивості поліімідної плівки, насиченої протонною іонною рідиною, досліджували двоконтактним методом за допомогою вимірювача іммітансу на частотах 0.1, 1.0 і 10 кГц в температурному інтервалі $25-180{ }^{\circ} \mathrm{C}$. Встановлено, що питома електропровідність матеріалу становить $2.7 \cdot 10^{-4}$ См/см при кімнатній температурі, досягаючи величини

*Corresponding author: Tel.: +38 044 5594622; fax: +38044 5599800; e-mail address: sergey.rogalsky@gmail.com (C) 2017 Oles Honchar Dnipro National University

doi: 10.15421/081708 
$\mathbf{1 . 5}^{10} \mathbf{1 0}^{-3} \mathrm{Cm} / \mathrm{cm}$ при $180{ }^{\circ} \mathrm{C}$. Таким чином, в даній роботі вперше отримано протонобмінну мембрану на основі комерційного полііміду технологічно простим методом, без додаткової стадії сульфування полімеру. Композитна мембрана Matrimid/БІМ-ТФСІ перспективна для використання у паливних елементах, які експлуатуються при підвищених температурах за відсутності зволоження.

Ключові слова: полімер - електролітна мембрана; поліімід; іонна рідина; паливні елементи; протона провідність

\title{
ПОЛИМЕР-ЭЛЕКТРОЛИТНАЯ МЕМБРАНА НА ОСНОВЕ СШИТОГО ПОЛИИМИДА И ПРОТОННОЙ ИОННОЙ ЖИДКОСТИ
}

\author{
Станислав Н. Махно, ${ }^{1}$ Оксана П. Тарасюк, ${ }^{2}$ Татьяна В. Чернявская, ${ }^{1}$ \\ Олег В. Джужа, ${ }^{2}$ Валерий И. Пархоменко, ${ }^{2}$ Сергей П. Рогальский ${ }^{2}$ \\ ${ }^{1}$ Институт химии поверхности им. А.А.Чуйко НАНУ, ул. Генерала Наумова, 17, Киев 03164, Украина \\ ${ }^{2}$ Институт биоорганической химии и небтехимии НАНУ, Харьковское шоссе, 50, Киев 02160, Украина
}

\section{Аннотация}

Целью работы было получение полимер-электролитной мембраны на основе промышленного полиимида Matrimid с высоким уровнем протонной проводимости при температурах выше $100{ }^{\circ} \mathrm{C}$. Синтезирована гидрофобная протонная ионная жидкость бис(трифторметилсульфонил)имид 1-бутилимидазолия (БИМТФСИ), которая была использована в качестве протонпроводящего электролита. Удельная электропроводность ионной жидкости, измеренная методом электрохимического импеданса, имеет

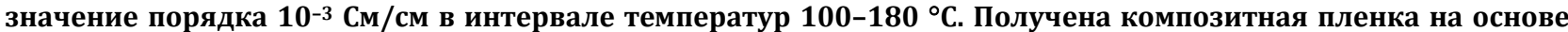
полиимида Matrimid, содержащая 70 \% ионной жидкости, поливом из раствора в метиленхлориде. Полиэфир Jeffamine ${ }^{\circledR}$ D-2000 использован в качестве сшивающего агента для полиимида. Согласно результатам механических и термических исследований, прочность на разрыв композита Мatrimid/БИМТФСИ составляет 18 мПа, а температура начала деструкции - $306{ }^{\circ}$. Электрофизические свойства полиимидной пленки, насыщенной протонной ионной жидкостью, исследовали двухконтактным методом с помощью измерителя иммитанса на частотах 0.1, 1.0 и 10 кГц в температурном интервале 25-180 ${ }^{\circ} \mathrm{C}$. Установлено, что удельная электропроводность материала составляет $2.7 \cdot 10^{-4}$ См/см при комнатной температуре, возрастая до величины $1.5 \cdot 10^{-3} \mathrm{Cm} / \mathrm{cm}$ при $180{ }^{\circ} \mathrm{C}$. Таким образом, в данной работе впервые получена протонобменная мембрана на основе коммерческого полиимида технологически простым методом, без дополнительной стадии сульфирования полимера. Композитная мембрана Matrimid/БIM-TФCI перспективна для использования в топливных элементах, которые эксплуатируются при температурах выше 100 으 при отсутствии увлажнения.

Ключевые слова: полимер-электролитная мембрана; полиимид; ионная жидкость; топливные элементы; протонная проводимость

\section{Вступ}

За останні 20 років спостерігається стійке підвищення інтересу дослідників до технології паливних елементів. Це пов'язано $з$ глобальними економічними проблемами, а також вичерпуванням вуглеводневих ресурсів - основного джерела енергії на сьогоднішній день. Безумовними перевагами паливних елементів $\epsilon$ доступність сировини для генерування електричної енергії (водень, метанол), а також відсутність забруднення довкілля при їх функціонуванні. Водневі паливні елементи можуть використовуватись як у великій енергетиці, так i замість стандартних джерел енергії в автомобілях i побутовій техніці [1-4]. Важливою складовою паливних елементів $\epsilon$ полімер-електролітна мембрана, яка запобігає безпосередній взаємодії між паливом і киснем, а також забезпечує перенесення в катодну область протонів, які утворились у результаті іонізації атомів водню в каталітичному шарі аноду. Питома іонна провідність мембрани в межах $10^{-3}-10^{-1}$ См/см вважається достатньою для застосування в паливному елементі. Протонобмінна мембрана повинна також мати високу механічну міцність, достатню для напресування на неї електродів і витримувати підвищені тиски реагентів [2; 4].

До недавнього часу найпоширенішими промисловими протонобмінними мембранами були перфторовані полімерні сульфокислоти Nafion [5]. Суттєвими недоліками таких матеріалів $€$ висока вартість i неможливість їх використання при температурі вище $80{ }^{\circ} \mathrm{C}$, оскільки вони забезпечують необхідний рівень протонної провідності лише в гідратованому стані [6]. Однак відомо, що економічність паливних елементів значно зростає при їх експлуатації в інтервалі температур 130-200 ${ }^{\circ} \mathrm{C}$, що зумовлено значним прискоренням електродних реакцій, а також зменшенням ризику отруєння платинових каталізаторів домішками монооксиду вуглецю, присутньому у водневому паливі $[1 ; 3]$.

В останні роки проводяться інтенсивні дослідження для розробки альтернативних полімер-електролітних мембран на основі 
економічно доступних полімерних матриць і нелетких безводних електролітів 3 іонною провідністю [2; 4; 7-12]. Серед останніх зростаючої популярності набувають протонні іонні рідини - рідкі або легкоплавкі солі, утворені бренстедівськими основами i кислотами [13-17]. Протонні іонні рідини містять мобільний протон у складі катіона, який здатний переміщуватись вздовж системи водневих зв'язків, утвореної кислотними та основними центрами [15]. Ці сполуки мають комплекс унікальних властивостей, зокрема низьку леткість, негорючість, високу протонну провідність і термічну стійкість, широкий діапазон електрохімічної стабільності. До перспективних протонпровідних електролітів відносять іонні рідини, які включають катіони диметилетиламонію, триетиламонію, імідазолію та аніони трифторметилсульфонат і біс(трифторметилсульфоніл)імід [13; 15].

В літературі описано нові перспективні полімер-електролітні мембрани для паливних елементів на основі сульфованих ароматичних поліімідів і протонних іонних рідин [18-20]. Введення сульфонатних груп до складу поліімідів надає їм розчинності в апротонних полярних розчинниках, а також значно підвищує сумісність 3 іонними рідинами. Це дає можливість отримувати композитні мембрани поливом 3 розчину 3 високим вмістом протонних іонних рідин (6080 \%). Питома електропровідність таких систем досягає $10^{-2} \mathrm{Cm} / \mathrm{cm}$ в області температур $120-160{ }^{\circ} \mathrm{C}$ [18; 20]. До недоліків сульфованих поліімідних мембран слід віднести високу вартість їх виготовлення, зумовлену використанням дорогих мономерів і токсичних розчинників.

У працях [21; 22] отримано композитні мембрани на основі макропористих поліімідів, насичених протонними іонними рідинами трифторметилсульфонатом триетиламонію і дібутилфосфатом 1-бутилімідазолію. Питома електропровідність композитів, які містили 65-70 \% іонних рідин, знаходилась в межах 0.01-0.1 См/см в області температур 115$130{ }^{\circ} \mathrm{C}$. Однак пориста структура мембран зумовлювала значне погіршення їх фізикомеханічних характеристик [21]. Крім того, висока розчинність у воді використаних іонних рідин може спричинювати їх низьку стійкість до вимивання водою, яка утворюється при роботі паливного елементу.

На відміну від традиційних ароматичних поліімідів, які розчиняються лише в концентрованій сульфатній кислоті, комерційно доступний поліімід Matrimid має високу розчинність в органічних розчинниках i $€$ зручним для отримання полімерних плівок [23]. Метою даної роботи було отримання нової протонобмінної мембрани на основі полііміду Matrimid і водостійкої протонної іонної рідини, яка має достатній рівень протонної провідності при температурах вищих за $100{ }^{\circ} \mathrm{C}$.

\section{Експериментальна частина}

Для синтезу іонних рідин використовували такі реактиви: імідазол, 1-бромбутан, ацетонітрил, диметилформамід, метиленхлорид, хлоридна кислота (37 \%), натрію сульфат (“Синбіас", Україна), натрію гідрид (60 \%-ва суспензія в парафіні, Fluka), літію біс(трифторметилсульфоніл)імід (Acros).

В якості полімерної матриці для протонобмінної мембрани використовували поліімід Matrimid®5218 (Huntsman, Швейцарія). Поліетерамін Jeffamine® D-2000 (Huntsman) використовували як зшиваючий агент для полііміду.

Протонні іонні рідини, які включають аніон біс(трифторметилсульфоніл)імід i катіони імідазолію (IM-TФCI) i 1-бутилімідазолію (БІМ-ТФСІ) синтезували за схемою 1:
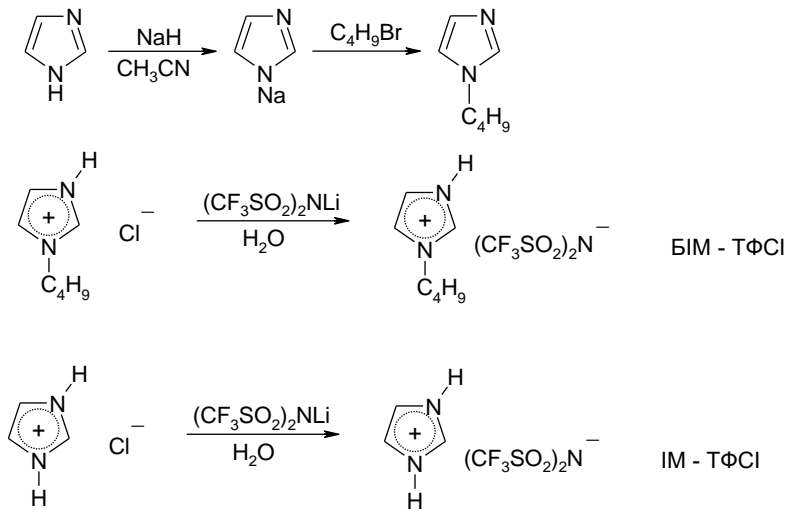

Scheme 1. Synthesis of protic ionic liquid BIM-TFSI

Схема 1. Синтез протонної іонної рідини БІМ-ТФСІ

15 г натрію гідриду (60 \%-ва суспензія в парафіні) суспендували в 50 мл гексану, відфільтровували і додавали при перемішуванні до 200 мл сухого ацетонітрилу. До суміші вводили порціями 24 г (0.35 моль) імідазолу і продовжували реакцію впродовж 6 год. До суспензії натрієвої солі імідазолу довавали 55 г (0.41 моль) 1-бромбутану, перемішували 4 год при кімнатній температурі і кип'ятили впродовж наступних 4 год. Осад натрію броміду відфільтровували, 
ацетонітрил відганяли за нормального тиску. Отриманий 1-бутилімідазол переганяли у вакуумі водоструменевого насосу при 115$120^{\circ} \mathrm{C}$.

5 г (0.04 моль) 1-бутилімідазолу розчиняли в 40 мл 1 М хлоридної кислоти і додавали при перемішуванні розчин літію біс(трифторметилсульфоніл)іміду (11.6 г, 0.04 моль) в 50 мл води. Утворений водонерозчинний шар екстрагували метиленхлоридом (2x30 мл) i сушили розчин натрій сульфатом. Після відгонки метиленхлориду отримували прозору рухливу рідину БІМ-ТФСІ.

1Н ЯМР-спектр (400 МГц, ДМСО-D6): $\delta$, м.ч. (J, Гц): $0.92\left(3 \mathrm{H}, \mathrm{T}, \mathrm{CH}_{3}, 2 \mathrm{~J}=7.3\right), 1.27(\mathrm{M}, 2 \mathrm{H}$, $\left.\mathrm{CH}_{2}\right), 1.75\left(\mathrm{M}, 2 \mathrm{H}, \mathrm{CH}_{2}\right), 4.14\left(\mathrm{~T}, 2 \mathrm{H}, \mathrm{NCH}_{2},{ }^{2} \mathrm{~J}=\right.$ 7.2), 7.53 (д, $1 \mathrm{H}, \mathrm{C}_{4}-\mathrm{H}$ ), 7.66 (д, $1 \mathrm{H}, \mathrm{C}_{5}-\mathrm{H}$ ), 8.84 (с, $1 \mathrm{H}, \mathrm{C}_{2}-\mathrm{H}$ ), 12.5-12.9 (ш с, $1 \mathrm{H}, \mathrm{NH}$ ).

${ }^{19} \mathrm{~F}$ ЯМР-спектр (188 МГц, ДМСО-D 6 ): $\delta$, м.ч. (J, Гц): $79.97\left(6 \mathrm{~F}, \mathrm{c}, \mathrm{CF}_{3}\right)$.

Синтез іонної рідини ІМ-ТФСІ

2 г (0.03 моль) імідазолу розчиняли в 15 мл 2 М хлоридної кислоти i додавали при перемішуванні розчин літію біс(трифторметилсульфоніл)іміду (8.7 г, 0.03 моль) у 40 мл води. Утворений водонерозчинний шар відділяли у розділювальній воронці і сушили у вакуумі 10 мбар при $100{ }^{\circ} \mathrm{C}$ протягом 12 год. Отримували IM-ТФСІ у вигляді аморфної сполуки білого кольору 3 температурою топлення $73^{\circ} \mathrm{C}$.

${ }^{1} \mathrm{H}$ ЯМР-спектр (400 МГц, ДМСО-D $): \delta$, м.ч. (J, Гц): 7.54 (c, 2H, C $\left.4-\mathrm{H}, \mathrm{C}_{5}-\mathrm{H}\right), 8.77$ (c, $\left.1 \mathrm{H}, \mathrm{C}_{2}-\mathrm{H}\right)$, 9.38 (ш с, 2H, NH).

Отримання композитних плівок полііміду Matrimid з іонними рідинами

Для отримання композитної плівки Matrimid/IM-ТФCI готували 5 \%-й розчин полііміду в диметилформаміді, додавали іонну рідину ІМ-ТФСІ у кількості 40-100\% відносно маси полімеру і перемішували 2 год. Розчин виливали на скляну поверхню i витримували при температурі $70{ }^{\circ} \mathrm{C}$ впродовж 24 год. Залишки розчинника видаляли 3 плівки у вакуумі 1 мбар при $80{ }^{\circ} \mathrm{C}$.

Для отримання композитної плівки Matrimid/БІМ-ТФСІ готували $10 \%$-й розчин полііміду в метиленхлориді, додавали іонну рідину БІМ-ТФСІ у кількості 65-150 \% відносно маси полімеру і перемішували 1 год. Розчин виливали на скляну поверхню i отримували полімерну плівку після видалення розчинника за кімнатної температури.

Для отримання зшитої плівки Matrimid/БIM-ТФСI методику, описану в працях [24; 25]. 0.5 г полііміду розчиняли в 10 мл метиленхлориду, додавали 0.2 г поліетераміну Jeffamine D-2000 і перемішували впродовж 4 год. До розчину полімеру додавали БІМ-ТФСІ (1.2 г), перемішували 1 год і виливали на скляну поверхню. Після видалення розчинника при кімнатній температурі отримували плівку зшитого полііміду, яка містила 70\% мас. протонної іонної рідини. Залишки метиленхлориду із полімерних плівок видаляли у вакуумі 10 мбар при $80{ }^{\circ} \mathrm{C}$ впродовж 12 год.

ІЧ-спектри поліімідних плівок отримували на спектрометрі Vertex-70 Bruker (Німеччина), обладнаного DTGS детектором. Полімерні зразки вводили в контакт із алмазним кристалом ATR (порушеного повного відбиття) і отримували спектр в області 4004000 cм$^{-1}$. Термогравіметричний аналіз (ТГА) проводили на дериватографі Q-1500D (PaulikErdey, Угорщина) у діапазоні температур 20$1000{ }^{\circ} \mathrm{C}$ при швидкості нагрівання $10{ }^{\circ} \mathrm{C} / \mathrm{xв}$ у повітрі. Механічні дослідження проводили 3 використанням розривної машини Р-50 (Мілаформ, Росія) при швидкості деформації 10 мм/хв. Електропровідність поліімідних композитів вимірювали двоконтактним методом на частотах $0.1,1.0$ і 10 кГц за допомогою вимірювача імітансу E7-14 в температурному інтервалі 25-180 ${ }^{\circ} \mathrm{C}$. Визначення комплексної електропровідності $\sigma^{*}=\sigma^{\prime}+i \sigma^{\prime}$ проводили за допомогою імпедансного спектрометра Solortron SI 1260 в діапазоні частот від $10^{-1}$ до $10^{6}$ Гц.

\section{Результати та їх обговорення}

На рис. 1 показано частотну залежність дійсної та уявної складової комплексної питомої електропровідності іонної рідини БІМ-ТФСІ. Залежність провідності від частоти змінного струму вказує на іонний механізм перенесення заряду. На низьких частотах (10-1 Гц) електропровідність системи знижується за рахунок накопичення зарядів на електродах, внаслідок чого відбувається блокування провідності подвійним електричним шаром. При збільшенні частоти іонна провідність зростає, а максимум на кривій 2 характеризує зменшення подвійного електричного шару в приелектродній області. При подальшому зростанні частоти (>104 Гц) спостерігається розсіювання зарядів при проходженні через середовище.

Серед досліджених імідазолієвих протонних іонних рідин найвищу 
Bulletin of Dnipropetrovsk University. Series Chemistry, 2017, 25(2), 49-57

електропровідність має біс(трифторметилсульфоніл)імід імідазолію (ІМ-ТФСI), яка становить $2.7 \cdot 10^{-2}$ См/см при $130{ }^{\circ} \mathrm{C}$ [13]. Перенесення протонів у середовищі ІМ-ТФСІ відбувається як за транспортним механізмом, так i за механізмом Гротгуса завдяки амфотерній природі молекул імідазолу [14]. Однак спроба отримання полімерелектролітної мембрани на основі полііміду Matrimid та іонної рідини IM-ТФСІ поливом 3 розчину в диметилформаміді була невдалою через відсутність плівкоутворення при вмісті іонної рідини вище 25 \%.

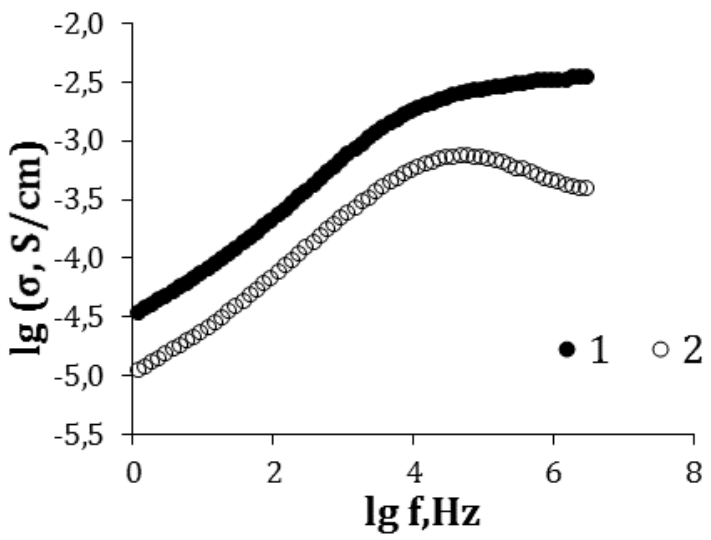

Fig. 1. Frequency dependences of real $\sigma^{\prime}(1)$ and imaginary $\sigma^{\prime \prime}(2)$ components of the electrical conductivity of BIM-TFSI protic ionic liquid at $20^{\circ} \mathrm{C}$

Рис. 1. Частотні залежності дійсної $\sigma^{\prime}(1)$ та уявної $\sigma^{\prime \prime}(2)$ складових комплексної питомої електропровідності іонної рідини БІМ-ТФСІ за температури $20^{\circ} \mathrm{C}$

Присутність алкільного замісника в катіоні імідазолію іонної рідини БІМ-ТФСІ суттєво знижує їі здатність до протонного перенесення, що можна пояснити відсутністю одного рухливого атома водню, а також стеричними перешкодами. Питома електропровідність БІМ-ТФСІ за кімнатної температури становить $3 \cdot 10^{-4}$ См/см, досягаючи мінімально необхідного рівня $10^{-3}$ См/см в інтервалі температур $90-180{ }^{\circ} \mathrm{C}$ (рис. 2). Незначний гістерезис прямого i зворотного ходу кривих залежності провідності від температури може означати присутність залишків води в іонній рідині. Лінійна залежність у напівлогарифмічному масштабі від температури вказує на можливість визначення енергії активації іонного перенесення за кутом нахилу кривої від оберненої температури згідно з рівнянням Ареніуса. Розрахована величина енергії активації електропровідності становить $0.14 \mathrm{eB}$.

Іонна рідина БІМ-ТФСІ має значно кращу сумісність із поліімідом Matrimid у порівнянні зі сполукою IM-ТФСІ, утворюючи гомогенні композитні плівки при вмісті до 40 \%. Однак основним недоліком таких композитів $\epsilon$ низька розривна міцність, на що вказують результати механічних тестувань (табл. 1). Ефективним методом покращення фізикомеханічних характеристик поліімідних мембран $є$ зшивання макромолекул полімеру хімічними агентами [26]. Згідно з літературними даними [24; 25], поліімід Matrimid легко взаємодіє з аліфатичними i ароматичними діамінами за кімнатної температури в метиленхлориді або хлороформі з перетворенням імідного циклу в амідні групи і, відповідно, утворенням зшитої структури (схема 2). Таким чином, застосування поліетераміну Jeffamine® D-2000 в якості зшиваючого агенту дозволило отримати композитні плівки Matrimid/БІМТФСІ з високим вмістом іонної рідини (70\%), які мають задовільні механічні характеристики (табл. 1). Аналіз ІЧ-спектрів (рис. 3, крива 2) свідчить про зменшення інтенсивності характеристичних піків поглинання імідного циклу при $1714 \mathrm{~cm}^{-1}$ (симетричні валентні коливання зв'язку $\mathrm{C}=0$ ) i $1362 \mathrm{~cm}^{-1}$ (валентні коливання зв'язку C-N), що підтверджує взаємодію імідних груп полімеру з поліетераміном.

Згідно з результатами ТГА (рис. 4, табл. 2), температура початку деструкції іонної рідини БІМ-ТФСІ (втрата маси 5 \%) становить $358{ }^{\circ} \mathrm{C}$, що вказує на її придатність для застосування у високотемпературних паливних елементах. Термічна стійкість композиту Matrimid/Jeffamine/БІМ-ТФСІ помітно нижча у порівнянні з чистим поліімідом та іонною рідиною, проте залишається на достатньому рівні, перевищуючи $300{ }^{\circ} \mathrm{C}$ (табл. 2).

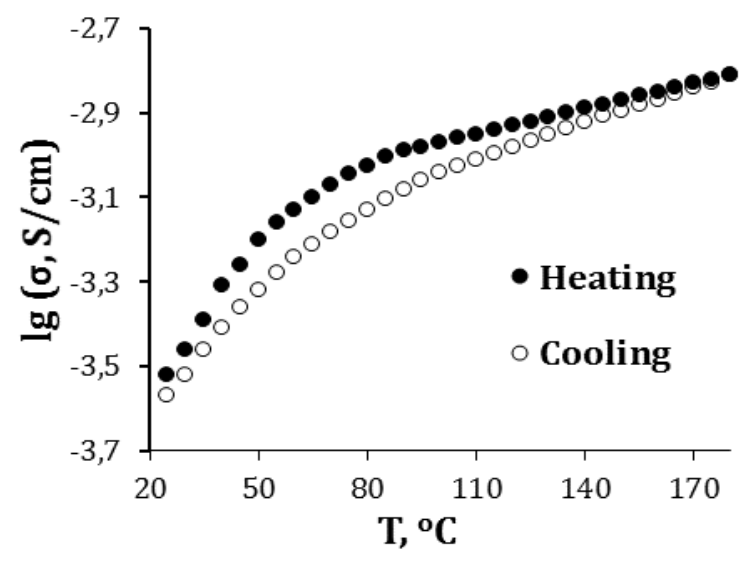

Fig. 2. Temperature dependences of ionic conductivity of BIM-TFSI at frequency of $1 \mathrm{kHz}$

Рис. 2. Температурні залежності іонної провідності БІМ-ТФСІ на частоті 1 кГц 
Mechanical properties of Matrimid/BIM-TFSI composite films

Механічні властивості композитних плівок Matrimid/БІМ-ТФСІ

\begin{tabular}{lcc}
\hline Sample & Tensile strength, MPa & Elongation at break, \% \\
\hline Matrimid & $38 \pm 2$ & $7 \pm 1$ \\
Matrimid/BIM-TFSI (40 \%) & $7 \pm 1$ & $9 \pm 2$ \\
Matrimid/Jeffamine (10 mol. \%) & $48 \pm 2$ & $12 \pm 2$ \\
Matrimid/Jeffamine/BIM-TFSI (70 \%) & $18 \pm 2$ & $8 \pm 1$ \\
\hline
\end{tabular}

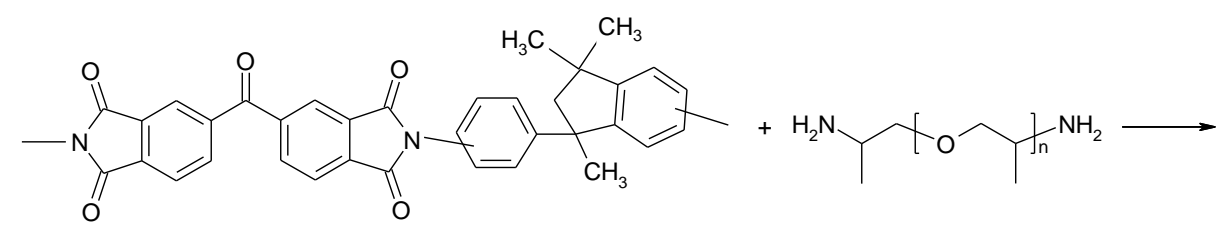<smiles>Cc1ccc2c(c1)C(C)(C)CC2(C)c1ccc(NC(=O)c2ccc(C(=O)c3ccc4c(c3)C(=O)N(C)C4=O)cc2C(=O)NCC(C)OCC(C)C(C)NC(=O)c2ccc(C(=O)c3ccc4c(c3)C(=O)N(C)C4=O)cc2C(=O)Nc2ccc(C3(C)CC(C)(C)c4cc(C)ccc4C3(C)C)cc2)cc1</smiles>

Scheme 2. Cross-linking of polyimide Matrimid with polyetheramine Jeffamine

Схема 2. Зшивання полііміду Matrimid взаємодією з поліетераміном Jeffamine

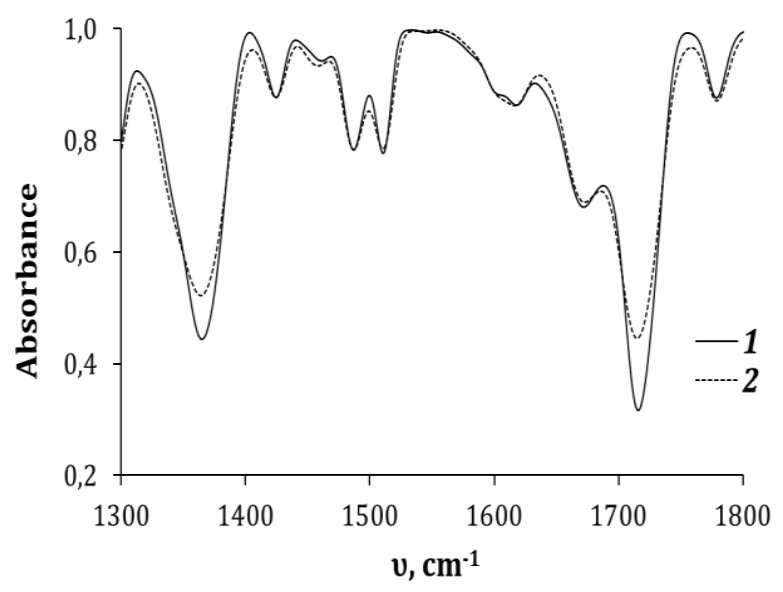

Fig. 3. IR-spectra of polyimide Matrimid (1) and Matrimid cross-linked with Jeffamine $₫$ D-2000 (10 mol. \%) (2)

Рис. 3. ІЧ-спектри полііміду Matrimid (1) і полііміду, зшитого поліетером Jeffamine $®$ D-2000 (10 mol. \%) (2)

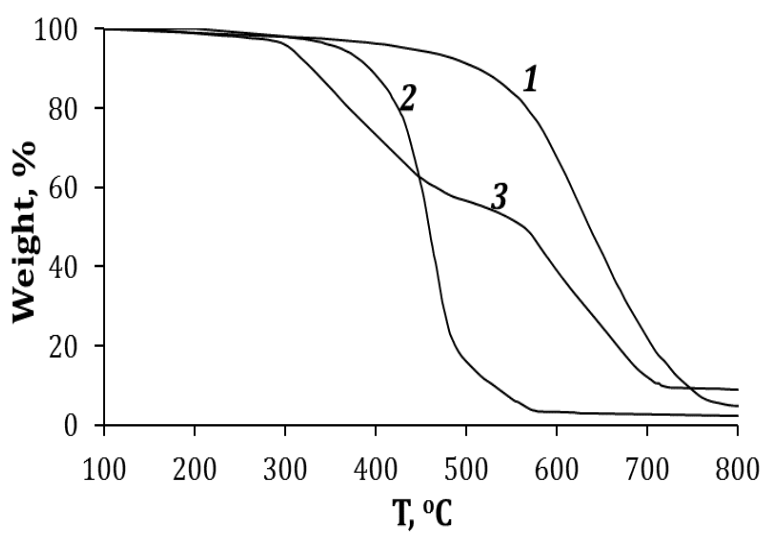

Fig. 4. TGA curves of polyimide Matrimid (1), BIM-TFSI (2) and Matrimid/Jeffamine/BIM-TFSI (3)

Рис. 4 Криві ТГА полііміду Matrimid (1), BIM-TFSI (2) і композиту Matrimid/Jeffamine/BIM-TFSI (3)

TGA data for polyimide samples

Table 2

езультати ТГА для поліімідних зразків

\begin{tabular}{lcccc}
\hline Sample & $\mathrm{T}_{\Delta \mathrm{m}=5 \%,},{ }^{\circ} \mathrm{C}$ & $\mathrm{T}_{\Delta \mathrm{m}=10 \%,{ }^{\circ} \mathrm{C}}$ & $\mathrm{T}_{\Delta \mathrm{m}=20 \%,}{ }^{\circ} \mathrm{C}$ & $\mathrm{T}_{\Delta \mathrm{m}=50 \%,}{ }^{\circ} \mathrm{C}$ \\
\hline Matrimid & 430 & 510 & 565 & 634 \\
BIM-TFSI & 358 & 391 & 424 & 459 \\
Matrimid/Jeffamine/BIM-TFSI & 306 & 329 & 370 & 457 \\
\hline
\end{tabular}


Bulletin of Dnipropetrovsk University. Series Chemistry, 2017, 25(2), 49-57

Результати електрофізичних досліджень композитних плівок Matrimid/БІМ-ТФСІ наведено на рис. 5, 6 і в табл. 3. Поліімідна плівка з низьким вмістом іонної рідини (40 \%) має максимальну питому електропровідність порядку $10^{-5} \mathrm{Cm} / \mathrm{cm}$ при $180{ }^{\circ} \mathrm{C}$ (рис. 5, табл. 3), що недостатньо для функціонування паливного елемента. Композитна мембрана на основі зшитого полііміду, яка містить 70 \%

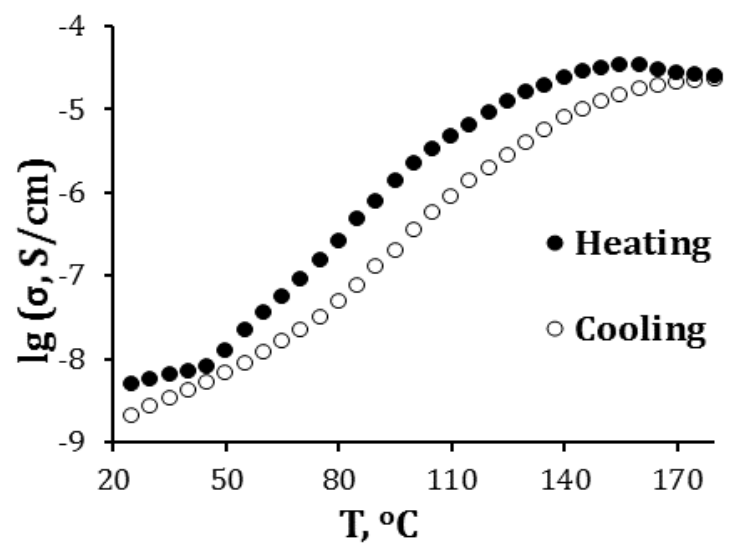

Fig. 5. Temperature dependences of ionic conductivity of Matrimid/BIM-TFSI (40\%) composite at frequency of $1 \mathrm{kHz}$

Рис. 5. Температурні залежності іонної провідності композиту Matrimid/БIM-ТФСI (40\%) на частоті 1 кГц
БІМ-ТФСІ, досягає необхідного рівня електропровідності 10-3 См/см при температурах вище $100{ }^{\circ} \mathrm{C}$ (рис. 6, табл. 3). Таким чином, вміст протонної іонної рідини $70 \%$ у полімерній матриці забезпечує утворення суцільного протонпровідного середовища, яке має питому електропровідність близьку до чистої іонної рідини.

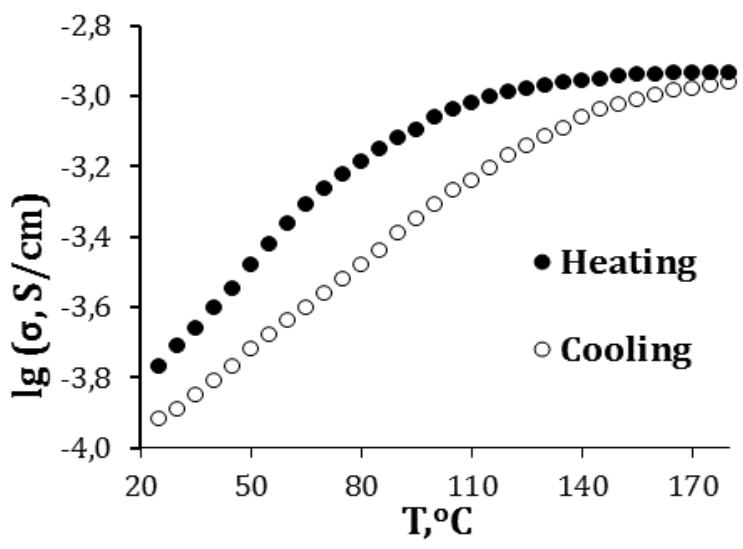

Fig. 6. Temperature dependences of ionic conductivity of Matrimid/Jeffamine/BIM-TFSI (70 \%) composite at frequency of $1 \mathrm{kHz}$

Рис. 6. Температурні залежності іонної провідності композиту Matrimid/Jeffamine/БІМ-ТФСI (70 \%) на частоті 1 кГц

Table 3

Таблиця 3

Electrical conductivity of Matrimid/BIM-TFSI composite membranes

Питома електропровідність композитних мембран Matrimid/БIM-ТФСI

\begin{tabular}{lcrrc}
\hline Sample & \multicolumn{3}{c}{$\sigma, \mathrm{S} / \mathrm{cm}$} \\
\cline { 2 - 5 } & $25^{\circ} \mathrm{C}$ & $80^{\circ} \mathrm{C}$ & $120^{\circ} \mathrm{C}$ & $180^{\circ} \mathrm{C}$ \\
\hline BIM-TFSI & $3 \cdot 10^{-4}$ & $9.4 \cdot 10^{-4}$ & $1.1 \cdot 10^{-3}$ & $1.5 \cdot 10^{-3}$ \\
Matrimid/BIM-TFSI (40 \%) & $5 \cdot 10^{-9}$ & $2.6 \cdot 10^{-7}$ & $9.1 \cdot 10^{-6}$ & $2.5 \cdot 10^{-5}$ \\
Matrimid/Jeffamine/BIM-TFSI (70\%) & $1.7 \cdot 10^{-4}$ & $6.6 \cdot 10^{-4}$ & $1 \cdot 10^{-3}$ & $1.1 \cdot 10^{-3}$ \\
\hline
\end{tabular}

\section{Висновки}

В даній роботі отримано нову протонобмінну мембрану на основі комерційного полііміду Matrimid технологічно простим методом без додаткової стадії сульфування полімеру. Синтезовано гідрофобну протонну іонну рідину біс(трифторметилсульфоніл)імід 1-бутилімідазолію (БІМ-ТФСІ), яку використано в якості протонпровідного електроліту. Температура початку деструкції БІМ-ТФСІ становить $358{ }^{\circ} \mathrm{C}$, а питома електропровідність досягає значення порядку $10^{-3}$ См/см при температурах вище $100{ }^{\circ} \mathrm{C}$. Отримано композитну плівку на основі зшитого полііміду Matrimid з високим вмістом протонної іонної рідини (70 \%) поливом 3 розчину в метиленхлориді. В якості зшиваючого агенту для полііміду використано поліетерамін Jeffamine® D-2000. Згідно з результатами механічних і термічних досліджень, композит Matrimid/Jeffamine/ БІМ-ТФСІ має міцність на розрив 18 мПа і $є$ термічно стійким до $306^{\circ} \mathrm{C}$. Питома електропровідність поліімідної плівки, насиченої протонною іонною рідиною, становить $2.7 \cdot 10^{-4}$ См/см при кімнатній температурі i має порядок $10^{-3}$ См/см в інтервалі температур $120-180^{\circ} \mathrm{C}$. Таким чином, отримані результати вказують на перспективність композиту Matrimid/БIMTФСІ для застосування в якості протонобмінної мембрани у паливних елементах, які експлуатуються при температурах вище $100{ }^{\circ} \mathrm{C}$ за відсутності зволоження. 


\section{Бібліографічні посилання}

[1] Behling, N. K. Fuel cells: current technology challenges and future research needs / N. K. Behling. - Oxford: Newnes, 2012. - $704 \mathrm{p}$.

[2] Zhang, H. Recent development of polymer electrolyte membranes for fuel cells / H. Zhang, P. K. Shen // Chem. Rev. - 2012. - Vol. 112, N 5. - P. 2780-2832.

[3] Breeze, P. Fuel cells / P. Breeze. - London: Academic Press, 2017. - 100 p.

[4] Kraytsberg, A. Review of advanced materials for proton exchange membrane fuel cells / A. Kraytsberg, Y. EinEli // Energy fuels. - 2014. - Vol. 28, N 12. - P. 73037330.

[5] Kumar, R. Graphite oxide/Nafion composite membranes for polymer electrolyte fuel cells / R. Kumar, C. Xu, K. Scott // Rcs. Adv. - 2012. - Vol. 2. P. 8777-8782.

[6] Sahu, A. K. Sulfonated graphene-Nafion composite membranes for polymer electrolyte fuel cells operating under reduced relative humidity / A. K. Sahu, K. Ketpang, S. Shanmugam, O. Kwon, S. Lee, H. Kim // J. Phys. Chem. C. - 2016. - Vol. 120, N 29. - P. 1585515866.

[7] Alcaide, F. Proton-conducting membranes from phosphotungstic acid-doped sulfonated polyimide for direct methanol fuel cell applications / F. Alcaide, G. Àlvarez, L. Ganborena, J. J. Iruin, O. Miguel, J. Alberto Blazquez // Polym. Bull. - 2009. - Vol. 62, N 6. P. 813-827.

[8] $\mathrm{Pu} \mathrm{H}$. Studies on anhydrous proton conducting membranes based on imidazole derivatives and sulfonated polyimide / H. Pu, H. Qin, L. Tang, X. Teng, Z. Chang // Elechtrochim. Acta. - 2009. - Vol. 54, N 9. P. 2603-2609.

[9] Zuo, Z. Novel blend membranes based on acid-base interactions for fuel cells / Z. Zuo, Y. Fu, A. Manthiram // Polymers. - 2012. - Vol. 4. - P. 1627-1644.

[10] Giang, G. Application of phosphoric acid and phyticacid doped bacterial cellulose as novel protonconducting membranes to PEMFC / G. Giang, J. Qiao, F. Hong // Int. J. Hydrogen Energy. - 2012. - Vol. 37, N 11. - P. 9182-9192.

[11] Chandan, A. High temperature (HT) polymer electrolyte membrane fuel cells (PEMFC) - A review / A. Chandan, M. Hattenberger, A. El-kharouf, S. Du, A. Dhir, V. Self, B. J. Pollet, A. Ingram, W. Bujalski // J. Power Sourc. - 2013. - Vol. 231, №1. - P. 264-278.

[12] Hwang; K. Preparation of polybenzimidazole-based membranes and their potential applications in the fuel cell system / K. Hwang, J.-H. Kim, S.-Y. Kim, H. Byun // Energies. - 2014. - Vol. 7. - P. 1721-1732.

[13] Susan, Md. A. B. H. Brønsted acid-base ionic liquids and their use as new materials for anhydrous proton conductors / Md. A. B. H. Susan, A. Noda, S. Mitsushima, M. Watanabe // Chem. Commun. - 2003, N 8. - P. 938-939.

[14] Noda, A. Brønsted acid-base ionic liquids as protonconducting nonaqueous electrolytes / A. Noda, Md. A. B. H. Susan, K. Kudo, S. Mitsushima // J. Phys. Chem. - B 2003. - Vol. 107, N 17. - P. 4024-4033.

[15] Nakamoto, H. Brönsted acid-base ionic liquids for fuel cell electrolytes / H. Nakamoto, M. Watanabe // Chem. Commun. - 2007, N 24. - P. 2539-2541.

[16] Greaves, T. Protic Ionic Liquids: Properties and Applications / T. Greaves, C. Drummond // Chem. Rev. - 2008. - Vol. 108, N 1. - P. 206-237.
[17] Lee, S.-Y. Nonhumidified intermediate temperature fuel cells using protic ionic liquids / S.-Y. Lee, A. Ogawa, M. Kanno, H. Nakamoto, T. Yasuda, M. Watanabe // J. Am. Chem. Soc. - 2010. - Vol. 132, N 28. - P. 97649773.

[18] Lee, S.-Y. Fabrication of protic ionic liquid/sulfonated polyimide composite membranes for non-humidified fuel cells / S.-Y. Lee, T. Yasuda, M. Watanabe // J. Power Sourc. - 2010. - Vol. 195, N 18. - P. 59095914.

[19] Deligöz, H. Development of a new highly conductive and thermomechanically stable complex membrane based on sulfonated polyimide/ionic liquid for high temperature anhydrous fuel cells / H. Deligöz, M. Yilmazoğlu // J. Power Sourc. - 2011. - Vol. 196, N 7. - P. 3496-3502.

[20] Chen, B.-K. 4,4'-oxydianiline (ODA) containing sulfonated polyimide/protic ionic liquid composite membranes for anhydrous proton conduction / B.-K. Chen, T.-Y. Wu, C.-W. Kuo, Y-C. Peng, I.-C. Shin, L. Hao, I.-W. Sun. // Int. J. Hydrogen Energy. - 2013. Vol. 38, N 26. - P. 11321-11330.

[21] Langevin, D. High-Temperature Ionic-Conducting Material: Advanced Structure and Improved Performance / D. Langevin, Q. T. Nguyen, S. Marais, S. Karademir, J.-Y. Sanchez, C. Iojoiu, M. Martinez, R. Mercier, P. Judeinstein, C. Chappey // J. Phys. Chem. C. - 2013. - Vol. 117. - N 30. - P.15552-15561

[22] Dahi, A. Polyimide/ionic liquid composite membranes for fuel cells operating at high temperatures / A. Dahi, K. Fatyeyeva, D. Langevin, C. Chappey, S. Rogalsky, O. Tarasyuk, S. Marais // Elechtrochim. Acta. - 2014. Vol. 130. - P. 830-840.

[23] Matrimid® 5218 technical datasheet. Way of Access: http://adhesives.specialchem.com/product/phuntsman-matrimid-5218

[24] Nistor, C. Composite membranes with cross-linked Matrimid selective layer for gas preparation / C. Nistor, S. Shishatskiy, M. Popa, S. P. Nunes // EEMG. - 2008. Vol. 7, N 6. - P. 653-659.

[25] Zhao, H.-Y. Effects of cross-linkers with different molecular weights in cross-linked Matrimid 5218 and test temperature on gas transport properties / H.-Y. Zhao, Y.-M. Cao, X.-L. Ding, M.-Q. Zhou, Q. Yuan // J. Membrane Sci. - 2008. - Vol. 323, N 1. - P. 176-184.

[26] Kausar, A. Progression from polyimide to polyimide composite in proton-exchange membrane fuel cells: a review / A. Kausar // Polym. Plast. Technol. Eng. 2017 (Accepted manuscript published online).

\section{References}

[1] Behling, N. K. (2012). Fuel cells: current technology challenges and future research needs. Oxford, UK: Newnes.

[2] Zhang, H., Shen, P. K. (2012). Recent development of polymer electrolyte membranes for fuel cells. Chem. Rev., 112(5), 2780-2832. https://doi.org/10.1021/cr200035s

[3] Breeze, P. (2017). Fuel cells. London, UK: Academic Press.

[4] Kraytsberg, A., Ein-Eli, Y. (2014). Review of advanced materials for proton exchange membrane fuel cells. Energy fuels., 28(12), 7303-7330. https://doi.org/10.1021/ef501977k

[5] Kumar, R., Xu, C., Scott, K. (2012). Graphite oxide/Nafion composite membranes for polymer electrolyte fuel cells. RCS. Adv., 2, 8777-8782. https://doi.org/10.1039/C2RA20225E 
[6] Sahu, A. K., Ketpang, K., Shanmugam, S., Kwon, O., Lee, S., Kim, H. (2016). Sulfonated graphene-Nafion composite membranes for polymer electrolyte fuel cells operating under reduced relative humidity. J. Phys. Chem. C. , 120(29), 15855-15866. https://doi.org/10.1021/acs.jpcc.5b11674

[7] Alcaide, F., Àlvarez, G., Ganborena, L., Iruin, J. J., Miguel, O., Alberto Blazquez, J. (2009). Proton-conducting membranes from phosphotungstic acid-doped sulfonated polyimide for direct methanol fuel cell applications Polym. Bull., 62(6), 813-827. https://doi.org/10.1007/s00289-009-0061-z

[8] Pu, H., Qin, H., Tang, L., Teng, X., Chang, Z. (2009). Studies on anhydrous proton conducting membranes based on imidazole derivatives and sulfonated polyimide. Elechtrochim. Acta, 54(9), 2603-2609. http://doi.org/10.1016/i.electacta.2008.10.057

[9] Zuo, Z., Fu, Y., Manthiram, A. (2012). Novel blend membranes based on acid-base interactions for fuel cells. Polymers, 4, 1627-1644. https://doi.org/10.3390/polym4041627

[10] Giang, G., Qiao, J., Hong, F. (2012). Application of phosphoric acid and phytic-acid doped bacterial cellulose as novel proton-conducting membranes to PEMFC. Int. J. Hydrogen Energy, 37(11), 9182-9192. https://doi.org/10.1016/j.ijhydene.2012.02.195

[11] Chandan, A., Hattenberger, M., El-kharouf, A., Du, S., Dhir, A., Self, V., Pollet, B. J., Ingram, A., Bujalski, W. (2013). High temperature (HT) polymer electrolyte membrane fuel cells (PEMFC) - A review. J. Power Sourc., 231(1), 264-278. https://doi.org/10.1016/i.jpowsour.2012.11.126

[12] Hwang, K., Kim, J.-H., Kim, S.-Y., Byun, H. (2014). Preparation of polybenzimidazole-based membranes and their potential applications in the fuel cell system. Energies, 7 ,

1721-1732. https://doi.org/10.3390/en7031721

[13] Susan, Md. A. B. H., Noda, A., Mitsushima, S., Watanabe, M. (2003). Brønsted acid-base ionic liquids and their use as new materials for anhydrous proton conductors. Chem. Commun., 8, 938-939. https://doi.org/10.1039/B300959A

[14] Noda, A., Susan, Md. A. B. H., Kudo, K., Mitsushima, S. (2003). Brønsted acid-base ionic liquids as protonconducting nonaqueous electrolytes. J. Phys. Chem. B, 107(17), 4024-4033. https://doi.org/10.1021/ip022347p

[15] Nakamoto, H., Watanabe, M. (2007). Brönsted acidbase ionic liquids for fuel cell electrolytes. Chem. Commun., 24, 2539-2541. https://doi.org/10.1039/B618953A

[16] Greaves, T., Drummond, C. (2008). Protic Ionic Liquids: Properties and Applications. Chem. Rev., 108(1), 206237.

https://doi.org/10.1021/cr068040u
[17] Lee, S.-Y., Ogawa, A., Kanno, M., Nakamoto, H., Yasuda, T., Watanabe, M. (2010). Nonhumidified intermediate temperature fuel cells using protic ionic liquids. J. Am. Chem. Soc., 132(28), 9764-9773. https://doi.org/10.1021/ja102367x

[18] Lee, S.-Y., Yasuda, T., Watanabe, M. (2010). Fabrication of protic ionic liquid/sulfonated polyimide composite membranes for non-humidified fuel cells. J. Power Sourc., 195(18), 5909-5914. http://doi.org/10.1016/i.jpowsour.2009.11.045

[19] Deligöz, H., Yilmazoğlu, M. (2011). Development of a new highly conductive and thermomechanically stable complex membrane based on sulfonated polyimide/ionic liquid for high temperature anhydrous fuel cells. J. Power Sourc., 196(7), 3496-3502. http://doi.org/10.1016/i.jpowsour.2010.12.033

[20] Chen, B.-K., Wu, T.-Y., Kuo, C.-W., Peng, Y-C., Shin, I.-C., Hao, L., Sun, I.-W. (2013). 4,4'-oxydianiline (ODA) containing sulfonated polyimide/protic ionic liquid composite membranes for anhydrous proton conduction. Int. J. Hydrogen Energy, 38(26), 1132111330. http://doi.org/10.1016/j.ijhydene.2013.06.053

[21] Langevin, D., Nguyen, Q. T., Marais, S., Karademir, S., Sanchez, J.-Y., Iojoiu, C., Martinez, M., Mercier, R., Judeinstein, P., Chappey, C. (2013). High-temperature ionic-conducting material: advanced structure and improved performance. J. Phys. Chem. C., 117(30), 15552-15561. https://doi.org/10.1021/jp312575m

[22] Dahi, A., Fatyeyeva, K., Langevin, D., Chappey, C., Rogalsky, S., Tarasyuk, O., Marais, S. (2014). Polyimide/ionic liquid composite membranes for fuel cells operating at high temperatures. Elechtrochim. Acta., 130, 830-840. http://doi.org/10.1016/i.electacta.2014.03.071

[23] Matrimid® 5218 technical datasheet. http://adhesives.specialchem.com/product/phuntsman-matrimid-5218

[24] Nistor, C., Shishatskiy, S., Popa, M., Nunes, S. P. (2008). Composite membranes with cross-linked Matrimid selective layer for gas preparation. EEMG, 7(6), 653659. http://omicron.ch.tuiasi.ro/EEM]

[25] Zhao, H.-Y., Cao, Y.-M., Ding, X.-L., Zhou, M.-Q., Yuan, Q. (2008). Effects of cross-linkers with different molecular weights in cross-linked Matrimid 5218 and test temperature on gas transport properties. J. Membrane Sci., 323(1), 176-184. http://doi.org/10.1016/j.memsci.2008.06.026

[26] Kausar, A. (2017). Progression from polyimide to polyimide composite in proton-exchange membrane fuel cells: a review. Polym. Plast. Technol. Eng., (Accepted manuscript published online). http://dx.doi.org/10.1080/03602559.2016.1275688 